\title{
BEGINNING A NATIONAL ABORIGINAL BIOGRAPHICAL REGISTER AT THE AUSTRALIAN INSTITUTE OF ABORIGINAL STUDIES*
}

\author{
Laurie Parkes and Diane Barwick
}

In 1968 W.E.H. Stanner complained to a nationwide radio audience that the several hundred thousand Aborigines who had lived and died since 1788 had been given 'no place in our past. ${ }^{1}$ The inadequacy of available biographical information about Aborigines still has serious consequences for the teaching of Australian history in schools and universities. In 1976 a search of Greenway's comprehensive bibliography and the catalogues and indexes of the Australian Institute of Aboriginal Studies Library yielded only eighty-eight publications which could be classified as reminiscence or biography. No more than a dozen books and perhaps the same number of biographical articles have been published since $1976 .^{2}$

The elders of every Aboriginal community of course preserve considerable biographical and genealogical knowledge. Recording this information is seen as an urgent task by many Aboriginal historians. Written information on named persons is also preserved in historical records, newspaper files, government archives and researchers' notebooks. Collating and indexing these scattered sources is an essential task for the development of Aboriginal history. Accurate and comprehensive records of the names and stories of Aborigines who played a significant part in past events could assist in 'rewriting' general histories and school text books so that the Aboriginal contribution is suitably recognized. A national collection of biographical material could also be a useful resource for the cultural and educational programs undertaken by Aboriginal communities and organisations.

The Australian Institute of Aboriginal Studies has recently begun a national Aboriginal Biographical Register, held at the Institute's Library in Canberra. The first stage of this project is a non-selective alphabetical card index of names and sources of information, modelled on the General Name Index maintained by the Australian Dictionary of Biography project at the Australian National University. With sufficient support from Aboriginal communities and interested researchers the register could become a central repository for a national collection of Aboriginal biographical data. Anyone wishing to consult the register or contribute information for it should contact either the Research Officer (History) or the Senior Bibliographer, Australian Institute of Aboriginal Studies, P.O. Box 553, Canberra City, ACT 2601. This note merely aims to draw attention to the existence of the register and the historiographical problems of such a project.

Institute committees first discussed the neglect of Aboriginal biography when planning an Oral History Conference for Aboriginal researchers in 1979. A report on the utility and feasibility of a national Aboriginal biographical 'dictionary' project was prepared for the Institute's Council (at the request of chairmen of all advisory committees) in April 1979. This memorandum noted that only fourteen of 3,159 entries $(0.004$ per cent) in the Australian Dictionary of Biography volumes covering the period 1788-1890 were devoted to Aborigines. Eleven more names had been selected for the period up to 1939.

- Bob Reece, Sylvia Hallam, Lois Tilbrook and Anna Haebich have inspired and supported the idea of a national biographical project since 1979. We also wisb to acknowledge the invaluable assistance of Rod Stroud of the National Library of Australia; Chris Cunneen and Jim Gibbney of the Australian Dictionary of Biography, and Marcia Langton, Warwick Dix, Vanessa Elwell, Rosslyn Fraser, Anna Shnukal, Tamsin Donaldson and the Library staff at the Australian Institute of Aboriginal Studies.

1 Stanner 1979:214.

2 Greenway 1968; Barwick, Urry and Bennett 1977:126-128. A substantial amount of biographical data has appeared in Aboniginal History since 1977 ; recent book-length studies are listed in Barwick 1981 and Gunson 1981. A methodological overview is provided by Shaw 1980. 
Aborigines as such were not distinguished in the A.D.B. General Name Index and the availability of information could be determined only by searching for a specific name. Dictionary staff members, who were eager to secure a better representation of Aborigines, suggested that A.I.A.S. Library holdings and indexes were the best source for retrieving biographical material. Mr Jim Gibbney gave expert advice on appropriate stages for the project, suggesting that the Papua New Guinea Biographical Register Short List, recently published by the University of Papua New Guinea, might be an appropriate model.

In October 1979 the A.I.A.S. Council agreed that Library staff should begin abstracting biographical material for the first stage of the project, a non-selective name register, and appointed a committee to advise on future planning. Members and co-opted advisors met on 19 May 1980. Dr Chris Cunneen of the Australian Dictionary of Biography; Dr R.H.W. Reece, Ms Sylvia Hallam and Ms Lois Tilbrook (researchers involved in the South West Aboriginal Studies project and the preparation of Aboriginal biographies for the Dictionary of Westem Australians); ${ }^{3} \mathrm{Mr}$ Stephen Albert of the National Aboriginal Education Committee; Mr Michael Mace, chairman of the A.I.A.S. Aboriginal and Torres Strait Islander Advisory Committee; Dr Diane Barwick (convenor); and Ms Rosita Henry of the A.I.A.S. Library attended.

Biographical dictionaries (volumes of selected biographies of deceased persons who were 'significant' in the past, organised by chronological periods) are a European form of literature, and rely upon European forms of record-keeping. A major problem in compiling biographies based upon oral history (as Mr Gibbney had pointed out) is the lack of 'vital statistics' - documentation or confirmation of dates. A second historiographical problem is that European notions of relevance have determined selection criteria for such dictionaries, and this kind of ethnocentrism had to be avoided. A third concern was that circulating or soliciting information about deceased persons might offend Aboriginal communities which maintain an indigenous convention forbidding the naming of the dead for some years. On the other hand many Aborigines have long expressed distress and resentment that the achievements and tribulations of their ancestors have been "written out of the histories' which shape the perceptions of generation after generation of Australian children. It was clear that the committee must consult Aboriginal opinion to ensure that the proposed project would be useful in fostering pride in Aboriginal identity and increasing public sympathy and understanding.

After discussion of these issues the committce advised Council that a national collection of biographical information would be a valuable historical resource and a vital educational tool. Their report recommended that the project be supervised by an expert committee which would consult and work with staff of the A.D.B. and Bicentennial History projects and with the National Aboriginal Conference and the various Aboriginal education consultative groups. The essential first stage was compilation of a non-selective name register (filed aphabetically and indexed by region and period) which listed known sources of information. Initially the register would be based on A.I.A.S. Library holdings. As a second stage specially-designed register forms should be made available to Aboriginal communities and organisations and other interested researchers. Individual files containing biographical data could be held in the Library for use by researchers and, perhaps, by writers commissioned to prepare selected volumes of biographies at a later stage of the project. The committee advised that the organization of the base register should be similar to that of the A.D.B. and that the same standards of confidentiality and propriety should be maintained. The register would include material on living persons but published volumes would be restricted to those whose lives had ended, as is normal 'dictionary' practice. The committee emphasised that Aboriginal communities must have a real voice in preparation of the register and in the selection of names for any publication: their criteria of historical relevance, 'eminence' or representativeness should influence the development of the 
project. The committee concluded that even if published volumes never eventuated, material collected for the biographical register would provide an important record of the achievements of Aboriginal people, and be a source of pride for generations to come.

Council necessarily deferred consideration of this report in October 1980 and in March 1981 referred it to the newly-appointed Interim History Committee, which was asked to brief Council on A.I.A.S. involvement in the rapidly-growing field of Aboriginal history. At their meetings in August-September 1981 the members: Ms Marcia Langton, Mr Michael Williams, Dr S.G. Foster (acting for Professor K.S. Inglis, a General Editor of the 1788-1988 Bicentennial History and chairman of the A.D.B.), and Dr Diane Barwick (Convenor) endorsed the previous report and recommended that the proposed History Committee should take responsibility for the biographical register, to be compiled initially by existing Library staff.

But although Library staff had shown sympathy - even enthusiasm - for the project, they were so overburdened that the work could be only a part-time task for one bibliographer. When the Interim History Committee's brief was discussed by Council in October 1981 the Principal, Mr Eric Willmot, stressed the educational value of this project and suggested that funds be earmarked for six months' research by a historian to plan and initiate a National Aboriginal Biographical Register.

Although Library staff will continue to add data to the register established by Ms Laurie Parkes in January-June 1982, financial constraints (and an impending Ministerial decision on a government review of Institute activities) preclude further development of the project. Researchers' interest in and use of the register will determine its ultimate fate. A suitably qualified researcher might well apply for an A.I.A.S. research grant to undertake biographical studies which could contribute to the expansion of the register. Work on an Aboriginal volume of the Dictionary of Western Australians is proceeding; it is to be hoped that sesquicentenary celebrations in other States and the national Bicentennial history project will stimulate further research on Aboriginal biography.

\title{
Organisation of the A.I.A.S. Aboriginal Biographical Register
}

Register cards are filed alphabetically, using Aboriginal names in preference to European names, although names are of course cross-referenced. To facilitate further research each name is 'tagged' - that is, identified by State of origin (and residence if this is different); occupational designations (which may include European forms of employment and indigenous occupations such as ceremonial leader, healer and so on); and by the clan, tribe or language group to which the person belongs if this information could be found. Each entry cites the source of information, using publishing citations in preference to standard catalogue notation so that the register could be incorporated into a subjectbased bibliography or, since each source is separately tagged and annotated and each name is indexed in numbered runs, bibliographies on individuals could also be made up easily. The cards are written in artist's needlepoint pen so clear photocopies can be made. The entry for Bungaree, for example, has a run of twenty-one separately tagged and annotated citations. The annotations are a brief description of the source, such as:

\author{
BLAIR, HAROLD \\ 1. Qld/Vic \\ Tenor \\ Foundation member Aboriginal Arts Board \\ Biog (monograph) illus. \\ Harrison, Kenneth. Dark Man White World \\ Novalit [Melbourne] 1975 \\ BLAIR, HAROLD \\ 2. Qld/Vic \\ Tenor \\ Foundation member Aboriginal Arts Board \\ Article on the setting up of the Board, \\ Aboriginal News 1(1) 1973:11-12.
}


There are currently some 1,100 'tagged' entries and 500 'strays' - names which have not been incorporated into the register because Parkes could not find sufficient information to tag them properly during her brief period of research. Further contributions by interested researchers will no doubt assist in 'tagging' more names, as' is the case with untagged entries in the General Name Index maintained by the A.D.B. Tagging is essential to make the register a useful reference tool, but it is a time-consuming task to read all sources, resolve discrepancies and eliminate unreliable information.

It is precisely because so little attention has been given to Aboriginal biography that the basic information necessary for tagging is often difficult to find. Frank Stevens ${ }^{4}$ has described the mechanics of racism in terms of depersonalization and dehumanization. The treatment of Aborigines as an amorphous mass is still a noticeable feature of media coverage. Descriptions of 'high profile' individuals pay insufficient attention to their Aboriginality. Abstracted from their Aboriginal background, they float in a limbo between tokenism and the museum. A more informed analysis of the lives of significant Aborigines is needed. For example, any historical account of the founding of European settlement at Sydney in 1788 which does not incorporate Stanner's $s^{3}$ reconstruction of the AboriginalEuropean dialogue makes very little sense as a study of cause and effect relationships which is usually considered to be one of the primary concerns of historians.

The problem of anonymous, group or community achievements is one which bedevils any historian working outside the hegemonic mainstream. This is as true of working class history and women's history as it is of Aboriginal history. Biographical research can shed new light on aspects of Australian society which have been poorly described. It can also demonstrate the narrow ideological base which has hitherto predetermined selection of 'the great men'. whose actions have preoccupied historians.

The fledgling Aboriginal Biographical Register is an attempt to list the names of men and women who have made undervalued contributions to the history of Australia. A national collection of biographical material could increase popular appreciation of the cultural strength and dynamic heterogeneity of Aboriginal society.

ADELAIDE S.A. and CANBERRA, A.C.T.

\section{BIBLIOGRAPHY}

Barwick, Diane. 'Writing Aboriginal history: comments on a book and its reviewers', Canberta Anthropology, 4(2), 1981:74-86.

Barwick, Diane, Nan Phillips and Tom Stannage. 'Biography', in Barwick, Diane, Michael Mace and Tom Stannage éds. Handbook for Aboriginal and Islander history. Canberra, 1979;21-27.

Barwick, Diane, James Urry and David Bennete 'A select bibliography of Aboriginal history and social change: theses and published research to $1976^{\circ}$, Aboriginal History, 1(2), 1977:111-169.

Greenway, John. Bibliography of the Australian. Aborigines and the native peoples of Tortes Strait to 1959. Sydney, 1963.

Gunson, Niel. 'Proud shoes: black family history in Australia', Aboriginal History, 5(2), 198 1:147-152.

Shaw, Bruce. 'Life history writing in anthropology: a methodological review', Mankind, 12(3), 1980: 226-233.

Stanner, W.E.H. " "The history of indifference thus begins" ', Aboriginal History, 1(1), 197 7:2-26.

- 'After the dreaming [The Boyer Lectures 1968]', in Stanner, W.E. H. White man got no dreaming: essays 1938-1973. Canberra, 1979:198-248.

Stevens, Frank. The politics of prejudice. Sydney, 1980.

Tilbrook, Lois. 'The South West Aboriginal Studies Project', Aboriginal History, 4(2), 1980:184-190. 